\title{
A case-control study of diarrhoea in children caused by Escherichia coli producing heat-stable enterotoxin (EAST-1)
}

\author{
J. VILA, A. GENE*, M. VARGAS, J. GASCON†, C. LATORRE* and M. T. JIMENEZ DE ANTA
}

Departments of Microbiology and $\dagger$ Infectious Diseases (Tropical Medicine Unit), Hospital Clinic, University of Barcelona, School of Medicine, Villarroel 170, 08036 Barcelona and *Department of Microbiology, Hospital de Sant Joan de Deu, Passeig de Sant Joan de Deu 2, 08950 Esplugues, Barcelona, Spain

\begin{abstract}
Escherichia coli strains associated with diarrhoeal disease have been classified into several types according to the pathogenic mechanism. Among these, enteroaggregative $E$. coli strains (EAggEC) have been associated with persistent childhood diarrhoea. Some strains of EAggEC produce a heat-stable toxin (EAST-1) that differs from others described previously. The main goal of this case-control study was to determine the prevalence of EAggEC and EAST-1-producing $E$. coli strains as a cause of diarrhoea in children in Spain and to study their in-vitro susceptibility to 21 antimicrobial agents. In the case group (115 children) $22(19 \%)$ isolates and four (3.5\%) isolates were EAST-1producing $E$. coli and EAggEC, respectively, whereas in the control group (79 children) four $(5 \%)$ isolates produced EAST-1 $(p=0.005)$ and three $(3.8 \%)$ isolates were EAggEC. The present study suggests that EAST-1-producing $E$. coli strains are associated with diarrhoeal diseases in Spanish children, whereas EAggEC strains are not. Moreover, EAST-1-producing $E$. coli strains showed a high susceptibility to all the antimicrobial agents tested except for ampicillin.
\end{abstract}

\section{Introduction}

The aetiology of diarrhoea in infants and children is quite different in developing and developed countries; in Spain Campylobacter spp. are the most common cause [1]. However, in general, $40-50 \%$ of cases remain undiagnosed microbiologically. At least six different diarrhoeagenic types of Escherichia coli have been identified. These include: enterotoxigenic $E$. coli (ETEC), enteroinvasive E. coli (EIEC), verotoxinproducing E. coli (VTEC) some strains of which are enterohaemorrhagic (EHEC), enteropathogenic E. coli (EPEC), enteroaggregative E. coli (EAggEC) and diffusely adherent $E$. coli (DAEC). EAggEC is associated with persistent diarrhoea in children [2] and it has been identified by a tissue culture adherence assay, where it presents an aggregative pattern, characterised by the fact that bacteria adhere to each other and appear as stacked-brick clumps on the HEp-2 cell [3]. Although EAggEC has been recognised as an important cause of acute and persistent diarrhoea in children in developing countries [2, 4], few studies

Received 8 Nov. 1997; revised version accepted 20 Jan. 1998.

Corresponding author: Dr J. Vila. have sought the presence of EAggEC in children in developed countries $[5,6]$. Some strains of EAggEC produce a heat-stable enterotoxin (EAST-1) different from other $E$. coli heat-stable enterotoxins, although it exhibits some functional relatedness to the heat-stable toxin STa of ETEC [7]. Recently, it has been shown that EAST-1 production is not restricted to enteroaggregative E. coli [8]. The main aim of this case-control study was to define the association of EAggEC or EAST-1-producing $E$. coli with diarrhoea in children $<5$ years old in Spain and to analyse the susceptibility to 21 antimicrobial agents.

\section{Materials and methods}

\section{Specimens}

Stool specimens were collected from children with diarrhoea who attended the outpatients' clinic of the Sant Joan de Deu Hospital, a paediatric hospital in Barcelona, Spain. Diarrhoea was defined as three or more stools per day for at least 3 days with a decrease in the consistency to an unformed state. The control group consisted of children who attended the hospital for non-diarrhoeal illness and who had not had diarrhoea in the previous 2 weeks. The samples were 
processed by conventional methods [9]. All the samples in which other enteropathogens were detected were discarded from the study. Therefore, the study was started with $115 E$. coli isolates from the case group and 79 from the control group.

\section{PCR to detect EAggEC and EAST-1-producing E. coli}

Two colonies of E. coli were picked from MacConkey agar and a PCR technique was used to identify the enteroaggregative characteristics and heat-stable toxin production. The two primers described by Schmidt et al. [10] were used to detect enteroaggregative $E$. coli. Two oligonucleotide primers were designed, based on the nucleotide sequence described by Savarinol et al. [7] to identify EAST-1 positive strains. The primers, 5'ATGCCATCAACACAGTATAT3' and 5'GCGAGTGACGGCTTTGTAGT3' were used to amplify the fragment of ast A gene, which codes for EAST-1, from nucleotides 132-241. Briefly, half a colony of each isolate was suspended in $25 \mu \mathrm{l}$ of distilled sterile water and boiled for $10 \mathrm{~min}$. After a short centrifugation $25 \mu \mathrm{l}$ of a reaction mixture containing $20 \mathrm{mM}$ Tris- $\mathrm{HCl}$ (pH 8.8), $100 \mathrm{~mm} \mathrm{KCl}, 3.0 \mathrm{mM} \mathrm{MgCl}_{2}$, gelatin $1 \% \mathrm{w} / \mathrm{v}$, $400 \mu \mathrm{MdNTPs}$ and $1 \mu \mathrm{M}$ of the appropiate primers, together with 2.5 Units of Taq polymerase (GibcoBRL) were added. The mixture was overlaid with oil and amplified with the following PCR programme: 35 cycles of $94^{\circ} \mathrm{C}$ for $1 \mathrm{~min}, 55^{\circ} \mathrm{C}$ for $1 \mathrm{~min}$ and $72^{\circ} \mathrm{C}$ for $1 \mathrm{~min}$; with a single final extension of $72^{\circ} \mathrm{C}$ for $5 \mathrm{~min}$. Amplified DNA products were resolved by electrophoresis in agarose $2 \% \mathrm{w} / \mathrm{v}$ gels containing ethidium bromide $0.5 \mathrm{mg} / \mathrm{L}$. The PCR product was extracted from the agarose gel and the DNA was sequenced with the Taq DyeDeoxiTerminator Cycle Sequencing kit and analysed in an automatic DNA sequencer (373A; Applied Biosystems).

\section{Susceptibility testing}

The susceptibility to antimicrobial agents was determined with an automated microdilution system (Microscan Walkaway, Baxter, Co. West Sacramento, CA, USA).

\section{Results and discussion}

By an assay with cultured HEp-2 or HeLa cells diarrhoeagenic $E$. coli strains may be classified on the basis of which adherence pattern they show: localised, diffuse or aggregative. However, discrepancies among different studies could be caused by the subjective interpretation of the adherence test, as well as to technical differences in the cell adherence procedure [11]. Therefore, the PCR technique described by Schmidt et al. [10] was used to detect EAggEC strains in this study and specific primers were designed to detect the ast $\mathrm{A}$ gene. Both PCR products had the expected size of $109 \mathrm{bp}$ corresponding to the amplified region of the ast $\mathrm{A}$ gene and $630 \mathrm{bp}$ corresponding to the amplified region of the aggA gene (Fig. 1). The purified product of the ast A gene was directly processed once for DNA sequencing and the sequence obtained from the amplified region was exactly the same as that previously described by Savarino et al. [11]. A very good correlation between the PCR technique for detecting enteroaggregative $E$. coli and the adherence test has been shown [12].

Table 1 indicates the frequency of isolation of EAggEC and EAST-1-producing E. coli from diarrhoeic and non-diarrhoiec patients. EAggEC was isolated from $3.5 \%$ (4 of 115) of children with diarrhoea compared with $3.8 \%$ ( 3 of 79 ) children without diarrhoea $(p=0.308)$, whereas EAST-1-producing E. coli was isolated from $19 \%$ (22 of 115 ) of children with diarrhoea compared with $5 \%$ (4 of 79) of children without diarrhoea $(p=0.005)$. Only one of the four $\mathrm{EAggEC}$ isolates from the case group showed production of EAST-1. This result is in contrast to that presented by Savarino et al. [8] who found that $41 \%$

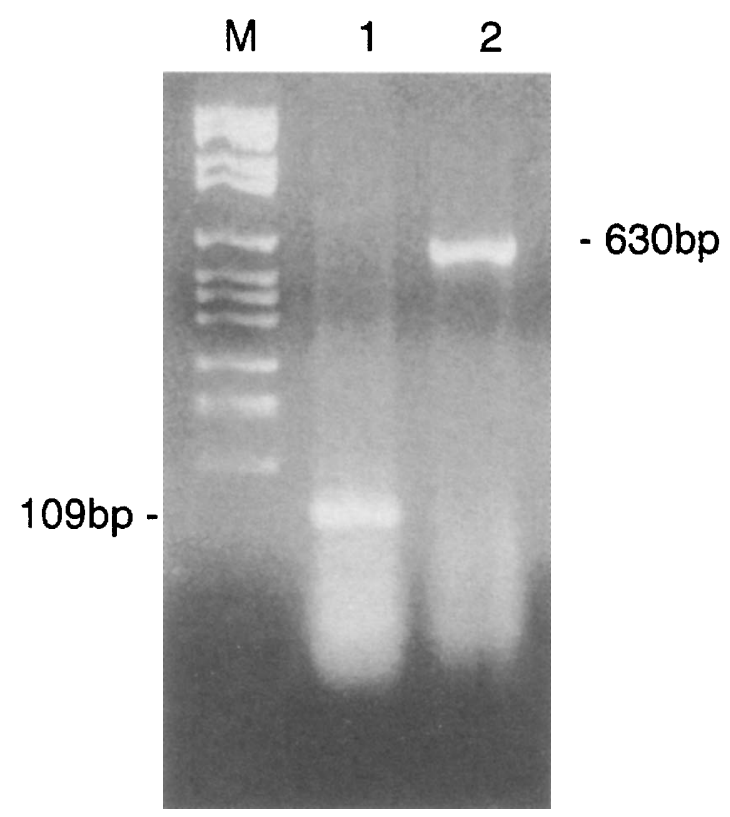

Fig. 1. Agarose gel electrophoresis of DNA fragments amplified with specific primers at ast gene (1), and to detect EAggEC (2), M, mol. wt marker (Boehringer).

Table 1. Enteroaggregative E. coli and EAST-1-producing $E$. coli from children with and without diarrhoea detected by PCR

\begin{tabular}{lccc}
\hline & \multicolumn{3}{c}{ Number of children } \\
\cline { 2 - 4 } E. coli & $\begin{array}{c}\text { Cases } \\
(\mathrm{n}=115)\end{array}$ & $\begin{array}{c}\text { Controls } \\
(\mathrm{n}=79)\end{array}$ & $\mathrm{p}$ value* \\
\hline Heat-stable toxin producing & 22 & 4 & 0.005 \\
Enteroaggregative & 4 & 3 & 0.308 \\
\hline
\end{tabular}

*Fisher's exact test 
of 227 EAggEC strains hybridised with the ast A probe.

The role of EAggEC strains as a cause of diarrhoea in children has been a matter of controversy. They have been associated with diarrhoea in India and Mexico $[13,14]$, but, in contrast, they were found in similar percentages in both cases and controls from Brazil, Chile, Thailand and Bangladesh $[11,12,15,16]$. From the present study, it seems that EAggEC strains are not associated with diarrhoea in children in Spain. The reason for these different results is not clear.

The in-vitro susceptibility of EAST-1-producing $E$. coli to several antimicrobial agents was investigated. The antimicrobial agents were distributed in three groups according to their activity. Group 1 comprised antimicrobial agents with good activity against EAST1 -producing $E$. coli (range of resistant strains from 0 $10 \%$ ), including cephalothin, cefuroxime, ceftazidime, cefoxitin, cefpirome, piperacillin, piperacillin plus tazobactam, imipenem, meropenem, azthreonam, trimethoprim-sulphamethoxazole, tobramycin, gentamicin, amikacin, norfloxacin and ciprofloxacin. Group 2 comprised antimicrobial agents with moderate activity (range of resistant strains 11-30\%), including ticarcillin, tetracyclines, chloramphenicol and nitrofurantoin. Group 3 comprised antimicrobial agents with low activity (percentage of resistant strains $>30 \%$ ) and contained only ampicillin.

In conclusion, the present study suggests that EAST-1producing $E$. coli strains are associated with diarrhoeal diseases in Spanish children, whereas EAggEC strains are not. Moreover, EAST-1-producing E. coli strains showed a high susceptibility to all the antimicrobial agents tested except ampicillin.

This work was supported in part by grant FIS94/0980 from Fondo de Investigaciones Sanitarias de la Seguridad Social, Spain and Mutual Médica, Barcelona, Spain.

\section{References}

1. Hosalot A, Corretger J, Falcó M, Rios M, Lambruschini N. Gastroenteritis aguda. Estudio prospectivo en niños de 1 a 24 meses. Arch Ped 1995; 46: 268-273

2. Savarino SJ. Diarrhoeal disease: current concepts and future challenges Enteroadherent Escherichia coli: a heterogeneous group of $E$. coli implicated as diarrhoeal pathogens. Trans $R$ Soc Trop Med Hyg 1993; 87(Suppl 3): 49-53.

3. Nataro JP, Kaper JB, Robins-Browne R, Pardo V, Vial P, Levine MM. Patterns of adherence of diarrheagenic Escherichia coli to HEp-2 cells. Pediatr Infect Dis J 1987; 6: 829-831.

4. Savarino SJ, Fasano A, Robertson DC, Levine MM. Enteroaggregative Escherichia coli elaborate a heat-stable enterotoxin demonstrable in an in vitro rabbit intestinal model. $J$ Clin Invest 1991; 87: 1450-1455.

5. Chan KN, Phillips AD, Knutton S, Smith HR, Walker-Smith JA. Enteroaggregative Escherichia coli: another cause of acute and chronic diarrhoea in England? $J$ Pediatr Gastroenterol Nutr 1994; 18: 87-91.

6. Forestier C, Meyer M, Fabre-Bonte $\mathrm{S}$ et al. Enteroadherent Escherichia coli and diarrhea in children: a prospective casecontrol study. J Clin Microbiol 1996; 34: 2897-2903.

7. Savarino SJ, Fasano A, Watson $\mathrm{J}$ et al. Enteroaggregative Escherichia coli heat-stable enterotoxin 1 represents another subfamily of E. coli heat-stable toxin. Proc Natl Acad Sci USA 1993; 90: 3093-3097.

8. Savarino SJ, McVeigh A, Watson $\mathrm{J}$ et al. Enteroaggregative Escherichia coli heat-stable enterotoxin is not restricted to enteroaggregative $E$. coli. J Infect Dis 1996; 173: 1019-1022.

9. Murray PR, Baron EJ, Pfaller MA, Tenover FC, Yolken RH (eds) Manual of clinical microbiology, 6th edn. Washington, DC American Society for Microbiology. 1995.

10. Schmidt H, Knop C, Franke S, Aleksic S, Heesemann J, Karch H. Development of PCR for screening of enteroaggregative Escherichia coli. J Clin Microbiol 1995; 33: 701-705.

11. Vial PA, Robins-Browne $\mathrm{R}$, Lior $\mathrm{H}$ et al. Characterization of enteroadherent-aggregative Escherichia coli, a putative agent of diarrheal disease. $J$ Infect Dis 1988; 158: 70-79.

12. Echeverria $\mathrm{P}$, Serichantalerg $\mathrm{O}$, Changchawalit $\mathrm{S}$ et al. Tissue culture-adherent Escherichia coli in infantile diarrhea. J Infect Dis 1992; 165: 141-143.

13. Bhan MK, Raj P, Levine MM et al. Enteroaggregative Escherichia coli associated with persistent diarrhea in a cohort of rural children in India. $J$ Infect Dis 1989; 159: 1061-1064.

14. Cravioto A, Tello A, Navarro A et al. Association of Escherichia coli HEp-2 adherence patterns with type and duration of diarrhoea. Lancet 1991; 337: 262-264.

15. Gomes TAT, Blake PA, Trabulsi LR. Prevalence of Escherichia coli strains with localized, diffuse, and aggregative adherence to HeLa cells in infants with diarrhea and matched controls. $J$ Clin Microbiol 1989; 27: 266-269.

16. Baqui AH, Sack RB, Black RE et al. Enteropathogens associated with acute and persistent diarrhea in Bangladeshi children $<5$ years of age. J Infect Dis 1992; 166: 792-796. 